Research Paper

\title{
LnCRNA HULC as a potential predictor of prognosis and clinico- pathological features in patients with digestive system tumors: a meta-analysis
}

\author{
Duo $\mathrm{Li}^{1}$, Rui Wang${ }^{1}, \mathrm{Na} \mathrm{Wu}^{1}$, Yongqiang $\mathrm{Yu}^{1}$ \\ ${ }^{1}$ Department of Gastroenterology, The First Affiliated Hospital of Hebei North University, Zhangjiakou, Hebei, China
}

Correspondence to: Yongqiang Yu; email: liduo@hebeinu.edu.cn

Keywords: IncRNA, HULC, digestive system cancer, prognosis

Received: June 11, $2021 \quad$ Accepted: February 2, 2022

Published: February 18, 2022

Copyright: $@ 2022$ Li et al. This is an open access article distributed under the terms of the Creative Commons Attribution License (CC BY 3.0), which permits unrestricted use, distribution, and reproduction in any medium, provided the original author and source are credited.

\begin{abstract}
Objective: This meta-analysis aimed to evaluate the correlation between IncRNA HULC, prognosis and clinicopathological characteristics in patients with digestive system tumors.

Methods: The relevant literatures were collected through PubMed, Web of Science and Embase up to February 2021. Hazard ratios (HRs) and $95 \%$ confidence intervals (Cls) were calculated to assess the prognostic value of HULC in patients with digestive system tumors. The clinicopathological characteristics of HULC in patients were estimated by odds ratios (ORs).

Results: A total of 14 studies involving 1312 patients were included. The up-regulated expression level of HULC was associated with poorer overall survival (OS) in patients with digestive system tumors (HR $=1.83,95 \% \mathrm{Cl}$ : 1.05-3.19, $P=0.033$ ). Subgroup analysis showed that cancer type (pancreatic cancer or gastric cancer), residence region (China, Japan or Korea), and specimen (serum) significantly associated between HULC and OS. In addition, high HULC expression significantly increased the risk of high TNM stage $(\mathrm{OR}=2.51,95 \% \mathrm{Cl}$ : 1.36 4.62, $P<0.05)$, poor differentiation $(\mathrm{OR}=1.38,95 \% \mathrm{Cl}: 1.02-1.87, P<0.05)$ and lymphatic node metastasis (LNM, $\mathrm{OR}=4.93,95 \% \mathrm{Cl}: 3.47-6.99, P<0.05)$.

Conclusions: High expression level of HULC is related to OS, TNM stage, differentiation and LNM. Therefore, HULC can be used as a new potential predictor for prognosis and clinicopathological features of patients with digestive system tumors.
\end{abstract}

\section{INTRODUCTION}

Digestive system tumor is a heterogeneous group of complex diseases affecting different organs, and the vast majority of it is malignancies [1,2]. Digestive system tumor is the common cause of cancer deaths [3, 4]. According to World Health Organization (WHO) classification of tumors, digestive system tumors include esophageal cancer, gastric cancer, small intestine cancer, hepatocellular carcinoma, gallbladder cancer, biliary tract cancer, pancreatic cancer and colorectal cancer. Although some studies have reported drugs or components with therapeutic potential for gastrointestinal cancer, such as allicin and curcumin [2, 5]. However, due to the challenge for clinical translation of current studies and the strong aggressiveness and metastatic ability of digestive system tumors, early diagnosis and surgery are crucial for reducing the mortality and prolonging the survival time of patients with digestive system tumors [5-7]. Therefore, the identification of new potential diagnostic and prognostic tumor biomarker is helpful for the early prevention and treatment of digestive system tumors.

Non-coding RNAs including long non-coding RNAs (lncRNAs), circular RNAs (circRNAs), and microRNAs (miRNAs) are responsible for the regulation of many cells signaling pathways [8]. Moreover, there are several 
studies suggesting that circRNAs, lncRNAs and miRNAs are epigenetic regulators with prognostic and therapeutic effects in digestive system tumors [9-11]. LncRNAs are defined as nonprotein-coding RNAs with lengths exceeding 200 nucleotides [12, 13]. Recent studies on formation and functional mechanisms of lncRNAs have shown that lncRNAs play a key role in regulating chromatin dynamics, gene expression and maintaining biological processes [14-16]. More and more evidences indicate that the dysregulation of lncRNA expression is closely related to the development of several human diseases, such as diabetes, sepsis, stroke, autoimmune diseases and cancer [8, 17-21]. Studies on tumors have shown that IncRNAs are involved in the pathogenesis of digestive system tumors through the regulation of autophagy [1]. Therefore, IncRNAs can be used as biomarkers and therapeutic targets for cancers.

Highly up-regulated in liver cancer (HULC) is located on the chromosome 6p24.3 and approximately 500nt in length [22]. In 2007, it was first reported to be significantly up-regulated in hepatocellular carcinoma, then, increasing studies have verified that it is dysregulated in various tumors such as pancreatic cancer, breast cancer and bladder cancer [23-26]. Recently, studies have shown that HULC is overexpressed in digestive system tumors to promote tumor development [24, 27, 28]. Therefore, we believe that high expression of IncRNA HULC in patients with digestive system tumors tend to have a poor prognosis.

Meta-analysis is an analytical method that could aggregate different studies to address deficiencies caused by small sample sizes and certain human errors. Although there have been studies evaluating the prognostic value of HULC in digestive system tumors through subgroup analysis [29]. In recent years, there have been several newly-published in this field. We conducted an updated and comprehensive meta-analysis of all published studies to provide more reliable evidence to evaluate the association between HULC and the prognosis and clinicopathological features in patients with digestive system tumors.

\section{MATERIALS AND METHODS}

\section{Literature retrieval strategies and selection criteria}

Articles for inclusion in this meta-analysis were searched in PubMed, Web of Science and Embase, up to February 2021. The keywords used in our literature search contained ("HULC" or "IncRNA HULC") and ("colorectal" or "gastric" or "esophageal" or "small intestine" or "hepatocellular carcinoma" or "gallbladder" or "biliary tract" or "pancreatic" or "liver" or "colon" or "rectal"). The inclusion and exclusion of the literatures were independently identified by two researchers.

\section{Inclusion and exclusion criteria}

\section{Inclusion criteria}

(1) The expression of IncRNA HULC in tumor tissues, serum and plasma of patients was measured; (2) According to the expression levels of HULC, patients were divided into high expression group and low expression group; (3) All patients suffered from digestive system tumors; (4) Studies were to investigate the role of HULC in digestive system tumors; (5) Survival information of patients, such as overall survival (OS), disease-free survival rate (DFS), progression-free survival rate (PFS), was provided; (6) The odds ratio (OR) or hazard ratio (HR), and the corresponding 95\% confidence interval (CI) could be calculated; (6) If there were repeated studies, the latest literature was included.

\section{Exclusion criteria}

(1) The study subjects were non-human; (2) Case reports, comments, reviews, letters and conference reports; (3) Non-English research; (4) Studies with insufficient clinical data; (5) Duplicate data or research.

\section{Quality assessment and data extraction}

The quality assessment and data extraction of the eligible studies were conducted by two researchers independently. A third researcher was used to resolve disagreements in eligibility, data extraction, or quality assessment. The Cochrane Non-Randomized Studies Methods Group recommended the use of the Newcastle-Ottawa Scale (NOS) to assess the quality of eligible studies (http://www.ohri.ca/programs/clinical_epidemiology/oxfo rd.asp) [30]. Publications with scores $\geq 6$ were included in this meta-analysis.

The following data were extracted: (1) The first author and year of publication; (2) Tumor types and detection methods; (3) demographic characteristics, including sample size, region, age, gender and follow-up time; (4) clinical characteristics of patients, including number of tumors, TNM stage, differentiation, lymph node metastasis (LNM) and distant metastasis (DM); (5) HR with 95\% CI for OS, DFS and PFS. If only KaplanMeier survival curves were available, the Engauge Digitizer v11.1 software could be used to obtain the available data to calculate the HR and the corresponding 95\% CI [31].

\section{Data mining from the TCGA and GTEx data set}

RNA-seq data and OS data for HULC in The Cancer Genome Atlas (TCGA) and The Genotype-Tissue 
Expression (GTEx) were extracted from GEPIA2 (http://gepia2.cancer-pku.cn/\#index) [32]. The median cutoff was chosen to divide the patients into two groups of high and low, and plot a Kaplan-Meier curve. $p<0.05$ was considered to be of prognostic value.

\section{Statistical analysis}

Stata SE14.0 software was used for statistical analysis in this meta-analysis. Heterogeneity among all included studies was assessed by $\mathrm{I}^{2}$ statistics and Q test. $\mathrm{I}^{2}>50 \%$, $\mathrm{P}<0.05$ indicated that the heterogeneity was statistically significant. Random-effects model should be applied to improve statistical stability. $\mathrm{I}^{2}<50 \%, \mathrm{P}>0.05$ indicated no statistical significance in heterogeneity, so the fixedeffects model was used. Data extracted from KaplanMeier survival curves and univariate analysis data were used for pooled analysis. The relationship between the expression level of HULC and the prognosis of patients with digestive system tumors was determined by HR and the corresponding 95\% CI. Also, the relationship between clinicopathological characteristics and HULC was assessed by OR and 95\% CI. We used subgroup analysis to analyze the sources of heterogeneity. Sensitivity analysis was used to assess the robustness of the meta-analysis. The Egger's test was used to evaluate the potential publication bias. HR $>1$ indicated a poor prognosis. $P$ value was calculated by two-tailed test, $P<$ 0.05 suggested statistically significant difference.

\section{RESULTS}

\section{Characteristics of eligible publications}

Figure 1 showed the process of literature selection. After excluding duplicate studies, a total of 138 studies were obtained from PubMed, Web of Science and Embase. 83 research articles were excluded based on

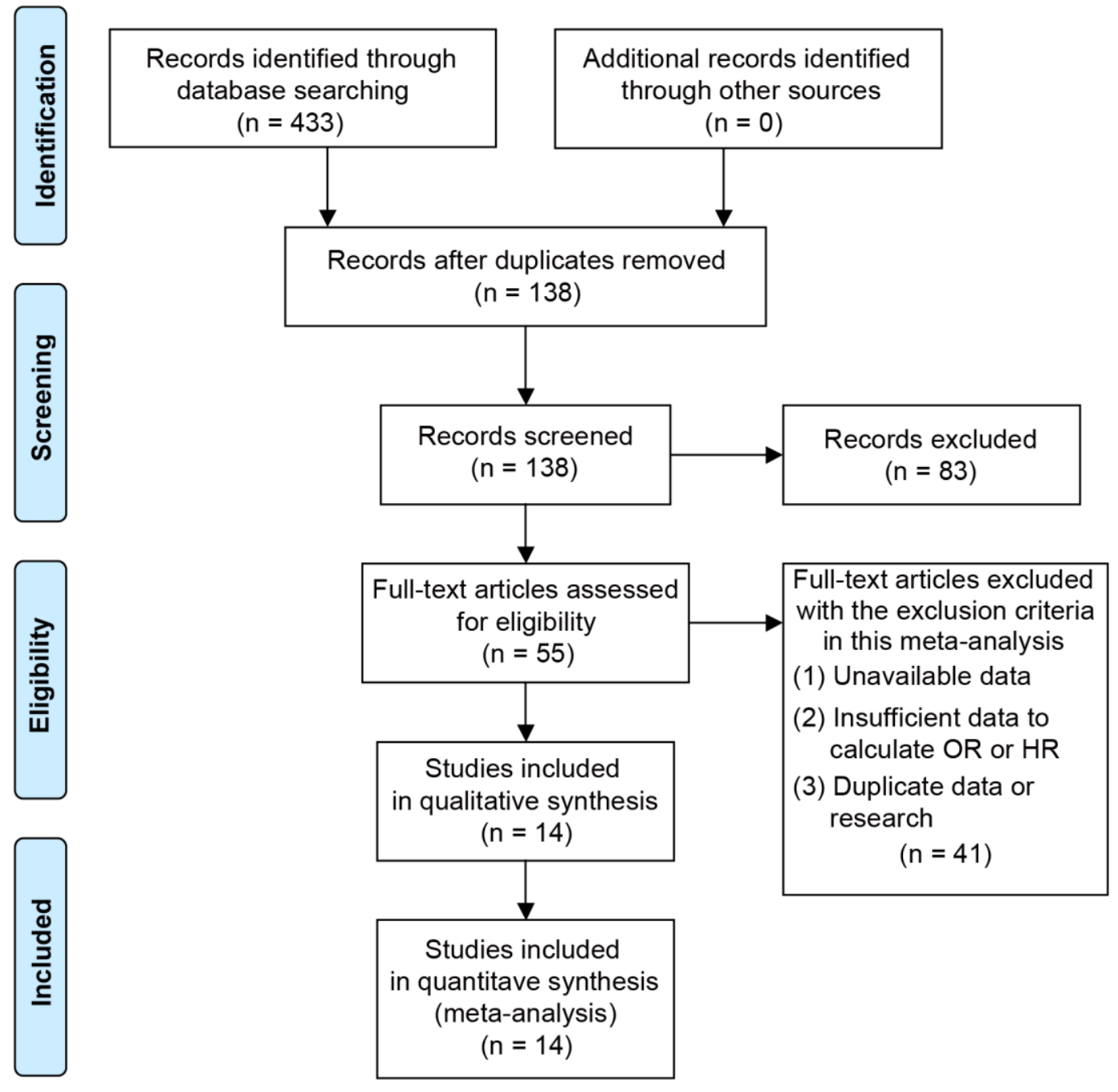

Figure 1. Flowchart for the process of search, selection and exclusion of studies. 
their titles and abstracts. After carefully reviewing the contents of the remaining 55 studies, a total of 14 articles met the inclusion criteria of this meta-analysis [24, 28, 33-44]. These studies were published between 2014 and 2020. There were 6 different kinds of digestive system tumors, including pancreatic cancer $(\mathrm{PC}, \mathrm{n}=2)$, hepatocellular carcinoma $(\mathrm{HCC}, \mathrm{n}=5)$, gastric cancer $(\mathrm{GC}, \mathrm{n}=3)$ and colorectal cancer (CRC, $\mathrm{n}$ $=4)$, in which CRC included colon cancer $(\mathrm{CC}, \mathrm{n}=1)$ and colon adenocarcinoma $(\mathrm{CA}, \mathrm{n}=1)$.

Table 1 summarized the main characteristics of all eligible studies in this meta-analysis. Four different regions were included in these 14 studies, China $(n=11)$, Japan $(n=1)$, South Korea $(n=1)$ and Germany $(n=1)$. A total of 1312 patients were included in this study. The sample size was a minimum of 30 and a maximum of 304 . There were 5 studies with a sample size exceeding 100. In 13 studies, the HULC expression levels were determined through quantitative real-time polymerase chain reaction (qRT-PCR). In 1 study, beadchip was used to detect the HULC expression. Nine studies reported the relationship between the expression level of HULC and the clinicopathological characteristics of patients, such as age, gender, tumor size, TNM stage and tumor differentiation. The NOS scores of all included studies were $\geq 6$.

\section{The relationship between the expression of IncRNA HULC and OS}

There were 10 studies, including 1050 patients with digestive system tumors, reported the correlation between HULC and OS. Due to the significant heterogeneity, a random-effects model was applied to calculate the pooled $\mathrm{HR}$ and the corresponding 95\% CI $\left(\mathrm{I}^{2}=88.5 \%, P<\right.$ $0.05)$. The results indicated that the OS of patients with up-regulated HULC expression had a worse prognosis than that of those with low HULC expression (HR = 1.83, 95\% CI: 1.01-3.30, $P=0.045$ ) (Figure 2A).

In term of cancer type, high expression of HULC was significantly related to poor survival prognosis in PC $(\mathrm{HR}=4.58,95 \% \mathrm{CI}: 1.57-13.37, \mathrm{P}=0.005)$ with significant heterogeneity $\left(\mathrm{I}^{2}=71.7 \%, \mathrm{P}=0.060\right)$, and in $\mathrm{GC}(\mathrm{HR}=3.35,95 \% \mathrm{CI}: 1.53-7.37, \mathrm{P}=0.003)$ with no significant heterogeneity $\left(\mathrm{I}^{2}=48.1 \%, \mathrm{P}=0.165\right)$ (Figure 2B). There was no significant correlation between HULC expression level and prognosis in HCC $(\mathrm{HR}=0.86,95 \% \mathrm{CI}: 0.44-1.66, \mathrm{P}=0.65)$ with significant heterogeneity $\left(\mathrm{I}^{2}=80.3 \%, \mathrm{P}=0.006\right)$, and in CRC $(\mathrm{HR}=1.37,95 \% \mathrm{CI}: 0.38-4.88, \mathrm{P}=0.63)$ with significant heterogeneity $\left(\mathrm{I}^{2}=75.4 \%, \mathrm{P}=0.017\right)$. According to subgroup analyses stratified by regions, the four geographic locations presented inconsistent results. In China, higher HULC expression level was related to poor prognosis $(\mathrm{HR}=3.30,95 \% \mathrm{CI}$ : 2.32 $4.69, \mathrm{P}<0.001)$ with no significant heterogeneity $\left(\mathrm{I}^{2}=\right.$ $14.7 \%, \mathrm{P}=0.32)$. However, it was associated with favorable prognosis in Japan (HR $=0.43$, 95\% CI: 0.25 $0.75, \mathrm{P}=0.003)$ and Korea (HR $=0.86,95 \% \mathrm{CI}: 0.77$ $0.96, \mathrm{P}=0.007)$. In Germany, the association between HULC expression level and prognosis of digestive system tumors was not statistically significant (HR $=0.34$, 95\%CI: 0.10-1.12, $\mathrm{P}=0.077$ ) (Figure 2C). When the studies were stratified by specimens, we found that the result of serum was statistically significant $(\mathrm{HR}=$ 5.91, 95\% CI: 3.34-10.47, $\mathrm{P}<0.001)$ with significant heterogeneity $\left(\mathrm{I}^{2}=0.0 \%, \mathrm{P}=0.361\right)$; nevertheless, the significant association was not found in tissue (HR = 1.45, 95\% CI: $0.79-2.64, \mathrm{P}=0.23$ ) with significant heterogeneity $\left(\mathrm{I}^{2}=83.7 \%, \mathrm{P}<0.001\right)$, plasma $(\mathrm{HR}=$ 2.15, 95\%CI: $0.89-5.19, \mathrm{P}=0.089)$ or serum exosomes $(\mathrm{HR}=0.34,95 \% \mathrm{CI}: 0.10-1.12, \mathrm{P}=0.077)$ (Figure 2D). The above results suggested that cancer type and region were the sources of heterogeneity in this meta-analysis.

Sensitivity analysis observed whether the pooled results were affected by eliminating each study in turn. Figure 3 showed the results of sensitivity analysis, which suggested that the results were reliable.

\section{The relationship between the expression of HULC} and tumor size, number, TNM stage, differentiation

There were 6 and 3 studies respectively reporting the tumor size and number of tumors in patients with digestive system tumors. The pooled results showed that the expression level of HULC was not correlated to tumor size $(\mathrm{OR}=1.74,95 \% \mathrm{CI}$ : $0.68-4.48, P=0.25)$ or number of tumors $(\mathrm{OR}=0.71,95 \% \mathrm{CI}$ : $0.47-1.09, P=$ 0.11) (Figure 4A, 4B). A random-effects model was used to analyze the relationship between HULC expression and TNM stage $\left(\mathrm{I}^{2}=63.5 \%, P=0.008\right)$. The pooled OR was 2.51 (95\%CI: $1.36-4.62, P=0.003)$, suggesting a significant correlation between the expression of HULC and TNM stage (Figure 4C). Thus, overexpression of HULC could easily increase the risk of high-stage tumors. Eight of included studies reported the differentiation of tumors. Since there was no significant heterogeneity, we used a fixed-effects model $\left(\mathrm{I}^{2}=0.0 \%, P=0.488\right)$ to analyze the data of tumor differentiation. The results suggested that the increased expression of HULC was significantly related to the poor differentiation of the digestive system tumors (OR $=1.38,95 \%$ CI: $1.02-1.87, P=0.035)$ (Figure 4D).

\section{The relationship between the expression of HULC and LNM, DM}

A total of 6 qualified literatures reported the occurrence of LNM in patients with digestive system tumors. Since 
Table 1. Basic characteristics of all qualified studies.

\begin{tabular}{|c|c|c|c|c|c|c|c|c|c|c|c|c|}
\hline \multirow{2}{*}{ Study } & \multirow{2}{*}{ Region } & \multirow{2}{*}{ Cancer } & \multirow{2}{*}{$\begin{array}{l}\text { Sample } \\
\text { size }\end{array}$} & \multicolumn{2}{|c|}{ Gender } & \multirow{2}{*}{ Specimen } & \multirow{2}{*}{ Method } & \multirow{2}{*}{ Survival analysis } & \multirow{2}{*}{ Outcome } & \multirow{2}{*}{ Cut-off } & \multirow{2}{*}{$\begin{array}{c}\text { Follow-up } \\
\text { (months) }\end{array}$} & \multirow{2}{*}{ NOS } \\
\hline & & & & $\mathbf{F}$ & $\mathbf{M}$ & & & & & & & \\
\hline Peng et al. 2014 & China & $\mathrm{PC}$ & 304 & 136 & 168 & tissue & qRT-PCR & Multivariate/Univariable & OS & mean & 36 & 8 \\
\hline Yang et al. 2015 & Korea & $\mathrm{HCC}$ & 240 & & & tissue & beadchip & Multivariate/Univariable & OS/DFS & median & 120 & 9 \\
\hline Li et al. 2015 & China & $\mathrm{HCC}$ & 66 & 13 & 53 & plasma & qRT-PCR & & & median & & 6 \\
\hline Li et al. 2016 & China & $\mathrm{HCC}$ & 38 & 9 & 29 & tissue & qRT-PCR & Kaplan-Meier curve & OS & mean & 60 & 7 \\
\hline Jin et al. 2016 & China & $\mathrm{GC}$ & 100 & 35 & 65 & serum & qRT-PCR & Kaplan-Meier curve & OS & median & 36 & 7 \\
\hline Yang et al. 2016 & China & $\mathrm{CRC}$ & 35 & & & tissue & qRT-PCR & Kaplan-Meier curve & OS & mean & 120 & 6 \\
\hline Zhang et al. 2016 & China & $\mathrm{GC}$ & 42 & & & plasma & qRT-PCR & Kaplan-Meier curve & OS & mean & 60 & 8 \\
\hline Sonohara et al. 2017 & Japan & $\mathrm{HCC}$ & 158 & 26 & 132 & tissue & qRT-PCR & Kaplan-Meier curve & OS/RFS & mean & 120 & 8 \\
\hline Zhang et al. 2018 & China & $\mathrm{CA}$ & 50 & 27 & 23 & tissue & qRT-PCR & & & median & & 6 \\
\hline Dong et al. 2019 & China & $\mathrm{CC}$ & 67 & 28 & 39 & tissue & qRT-PCR & Kaplan-Meier curve & OS & mean & 60 & 7 \\
\hline Oehme et al. 2019 & Germany & CRC & 52 & 19 & 33 & serum exosome & qRT-PCR & Kaplan-Meier curve & OS & median & 100 & 6 \\
\hline Cao et al. 2019 & China & $\mathrm{HCC}$ & 30 & 21 & 9 & $\begin{array}{l}\text { tissue, serum } \\
\text { exosome }\end{array}$ & qRT-PCR & & & mean & & 6 \\
\hline Liu et al. 2020 & China & GC & 116 & 40 & 76 & tissue & qRT-PCR & & & median & & 7 \\
\hline Ou et al. 2020 & China & $\mathrm{PC}$ & 60 & 17 & 43 & serum & qRT-PCR & Multivariate/Univariable & OS & median & 60 & 9 \\
\hline
\end{tabular}

$\mathrm{PC}$, pancreatic cancer; $\mathrm{HCC}$, hepatocellular carcinoma; GC, gastric cancer; $\mathrm{CRC}$, colorectal cancer; $\mathrm{CC}$, colon cancer; $\mathrm{CA}$, colon adenocarcinoma; $F$, female; $M$, male; OS, overall survival; DFS, disease-free survival; RFS, recurrence-free survival.

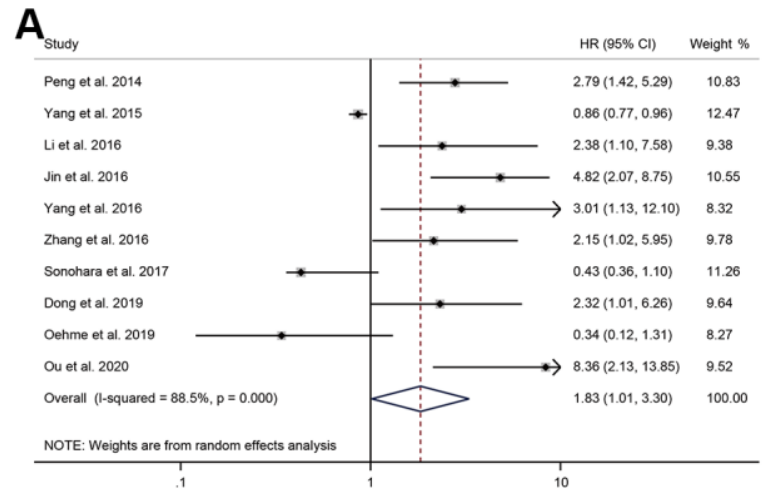

C

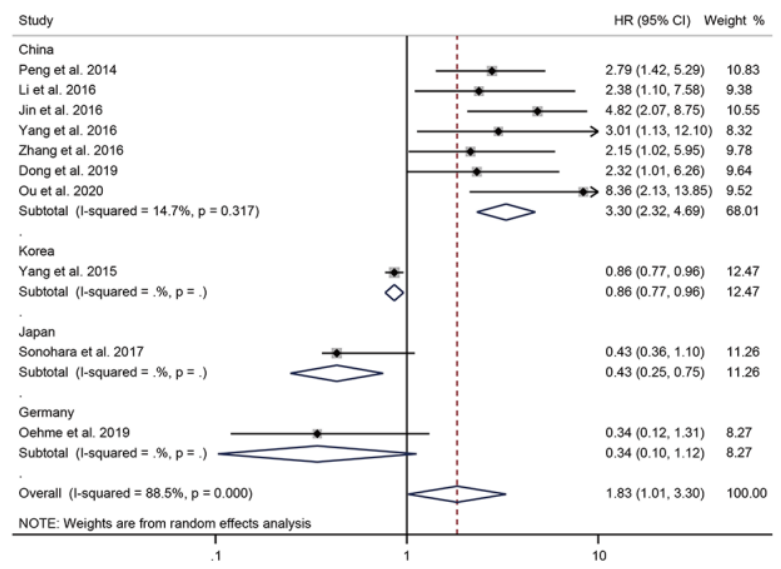

B

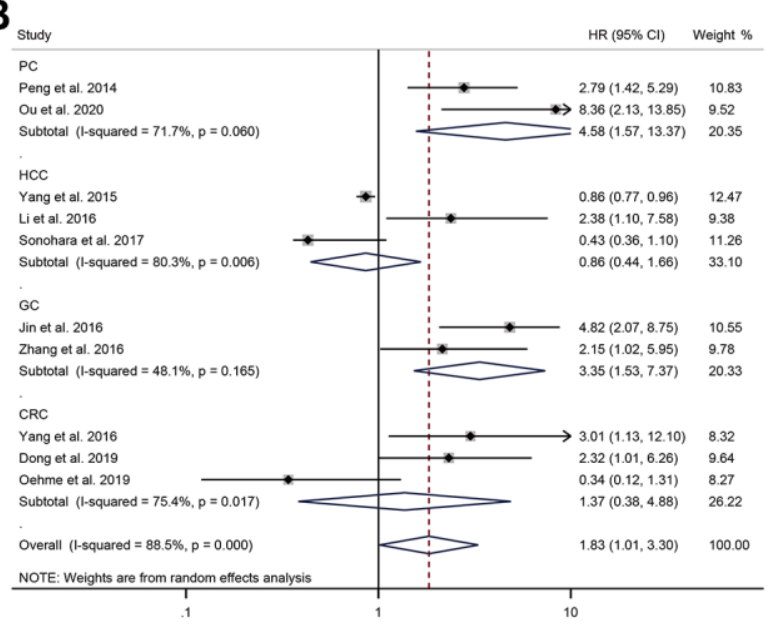

D

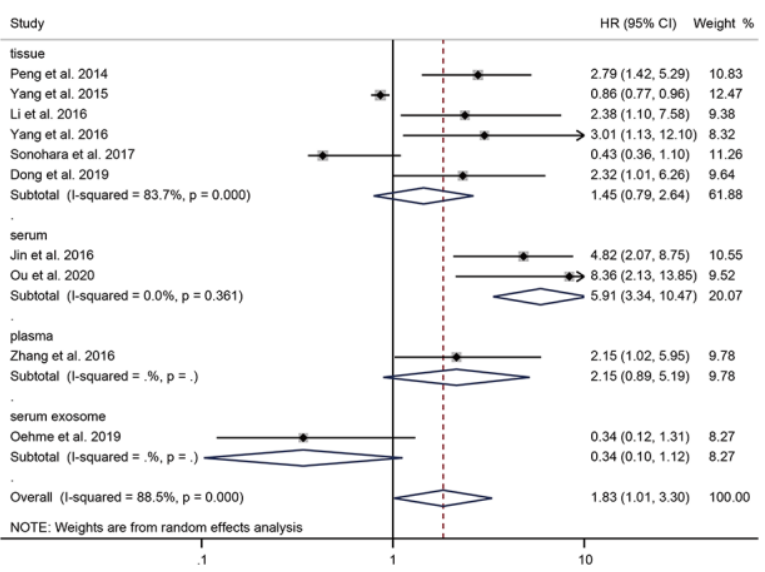

Figure 2. The correlation analysis between HULC expression level and OS. (A) Forest plot of the correlation between HULC expression level and OS in patients with digestive system tumors. (B) Subgroup analysis of HRs of OS according to the cancer type. (C) Subgroup analysis of HRs of OS according to the regions. (D) Subgroup analysis of HRs of OS according to the specimens. 


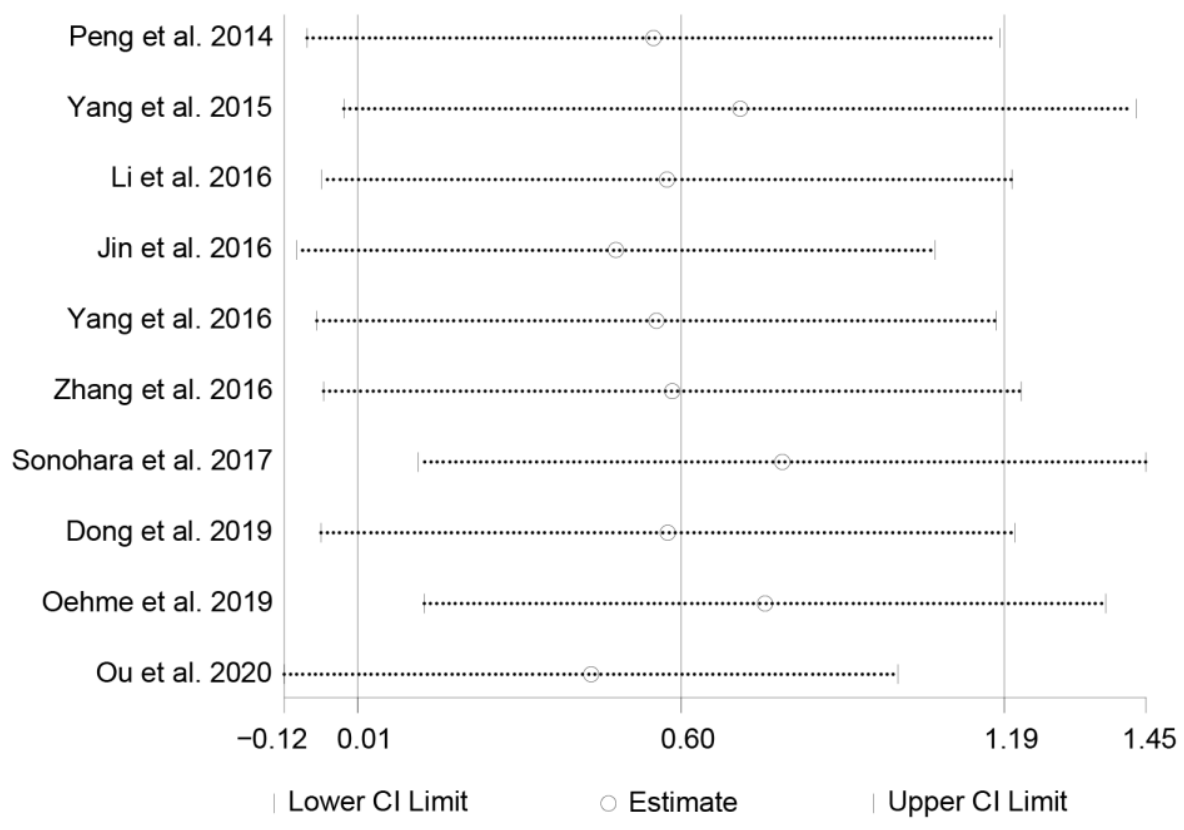

Figure 3. The sensitivity analysis on the correlation between HULC expression level and OS.

A

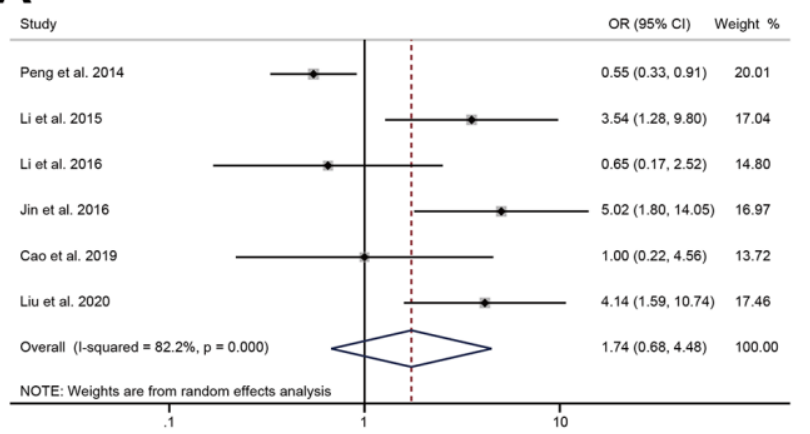

C

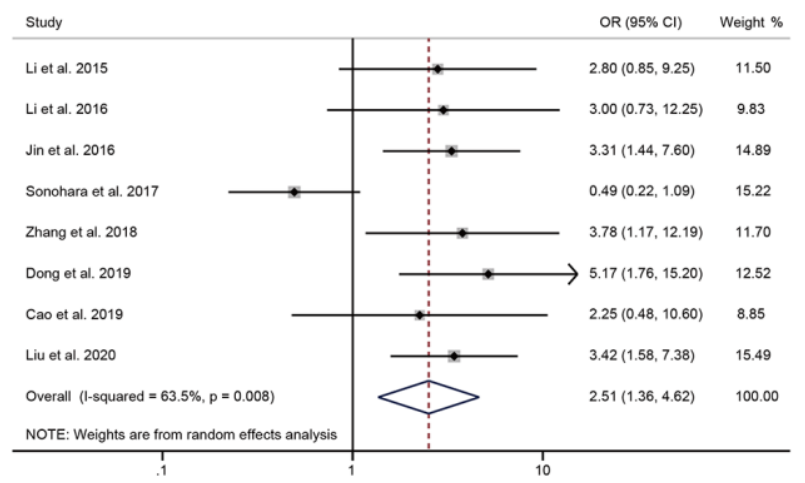

B

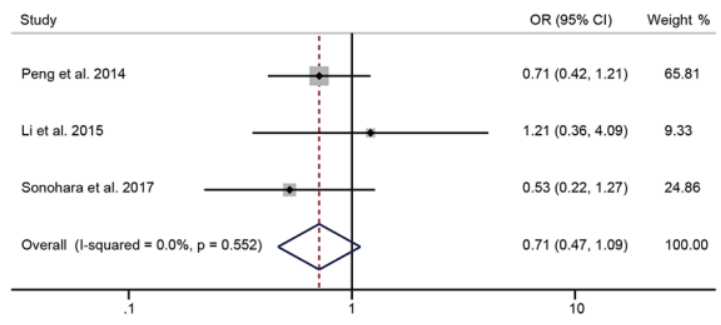

D

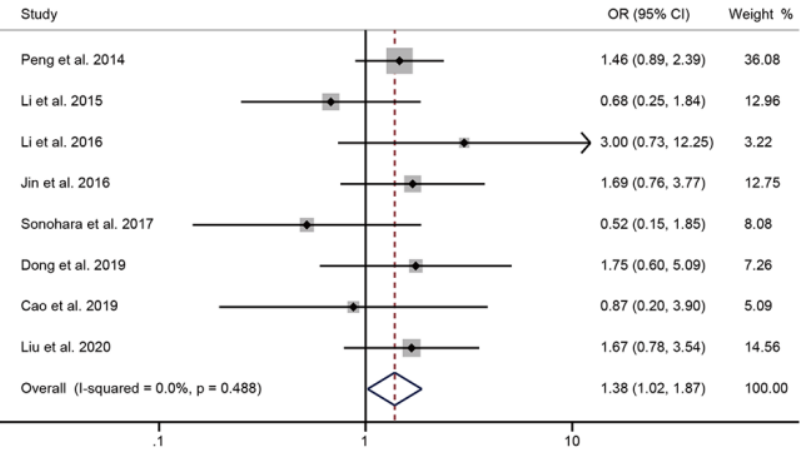

Figure 4. The correlation between HULC expression level and tumor characteristics. (A) The forest plot of ORs for the correlation between HULC expression and tumor size in patients with digestive system tumors; (B) The forest plot of ORs for the correlation between HULC expression and number of tumors in patients with digestive system tumors; (C) The forest plot of ORs for the correlation between HULC expression and TNM stage in patients with digestive system tumors; (D) The forest plot of ORs for the correlation between HULC expression and differentiation in patients with digestive system tumors. 
no significant heterogeneity was found, we adopted a fixed-effects model $\left(\mathrm{I}^{2}=26.9 \%, P=0.233\right)$. The pooled result indicated that cancer patients with high HULC expression had higher risk of LNM than those with low HULC expression $(\mathrm{OR}=4.93,95 \%$ CI: 3.47-6.99, $P<$ 0.001 ) (Figure $5 \mathrm{~A}$ ). $\mathrm{I}^{2}=73.1 \%, P=0.011$ suggested significant heterogeneity, so a random-effects model was used for the pooled analysis of DM. We found that high HULC expression was not significantly correlated with the DM of tumors $(\mathrm{OR}=3.18,95 \%$ CI: 0.69 $14.57, P=0.14$ ) (Figure 5B).

\section{The relationship between the expression of HULC and patients' age, gender}

In 5 studies ( 1 on pancreatic cancer, 2 on hepatocellular carcinoma, and 2 on gastric cancer), the high expression of HULC was not significantly related to the age of patients $(\mathrm{OR}=0.78,95 \% \mathrm{CI}: 0.55-1.10, P=0.16)$
(Figure 6A). The gender of patients was mentioned in 9 qualified studies. Since the heterogeneity was not significant, we used a fixed-effects model $\left(\mathrm{I}^{2}=0.0 \%, P\right.$ $=0.867)$. The pooled OR was 1.01 (95\% CI: 0.75-1.35, $P=0.95)$, indicating that the overexpression of HULC was not significantly associated with the gender of patients (Figure 6B).

\section{Assessment of publication bias}

To assess the publication bias in the current study, we performed an Egger's linear regression test. The Egger's test and linear regression plot was shown in Figure 7. Moreover, there was no statistically significant publication bias in OS $(P=0.059)$, age $(P=0.61)$, gender $(P=0.72)$, tumor size $(P=0.25)$, TNM stage $(P=0.25)$, differentiation $(P=0.51)$, number of tumors $(P=0.77), \operatorname{LNM}(P=0.33)$ and DM $(P=0.19)$.

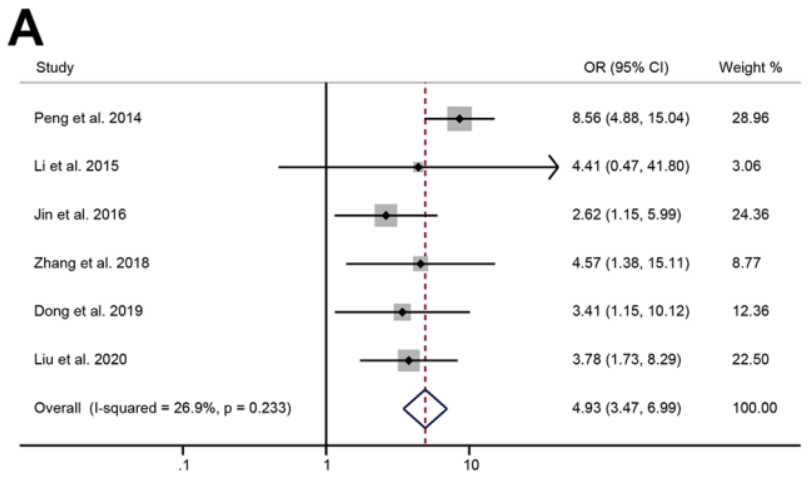

B

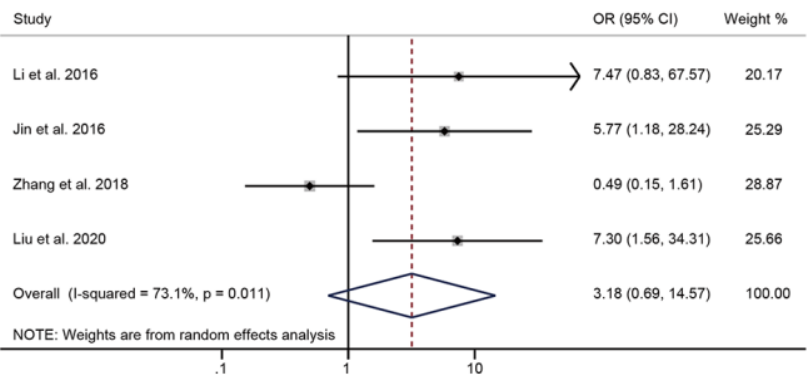

Figure 5. The correlation between HULC expression level and metastasis. (A) The forest plot of ORs for the correlation between HULC expression and lymphatic node metastasis in patients with digestive system tumors; (B) The forest plot of ORs for the correlation between HULC expression and distant metastasis in patients with digestive system tumors.

A

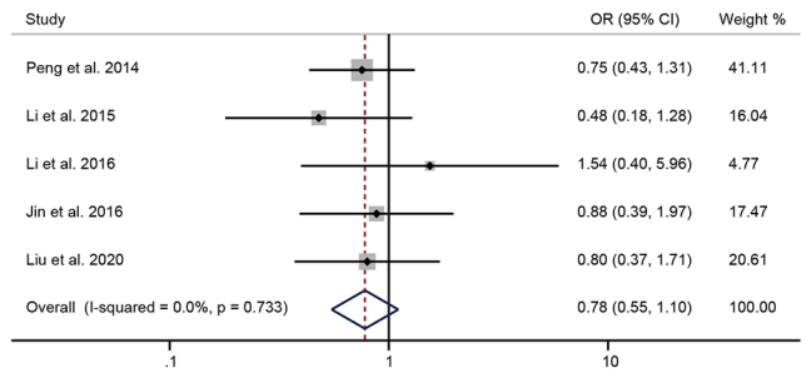

B

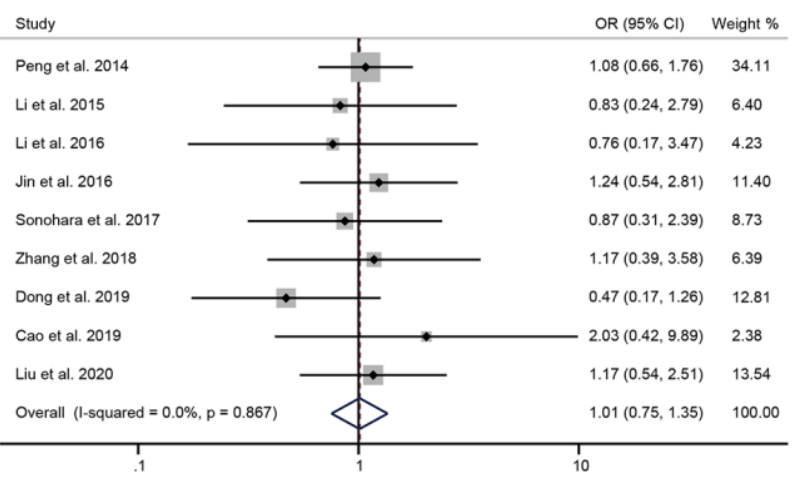

Figure 6. The correlation between HULC expression level and the patient's age, gender. (A) The forest plot of ORs for the correlation between HULC expression and age in patients with digestive system tumors; (B) The forest plot of ORs for the correlation between HULC expression and gender in patients with digestive system tumors. 


\section{Results in TCGA and GTEx data set}

The prognostic value of HULC was further verified by retrieving the clinical data from TCGA and GTEX data set. We finally retrieved 5 GI cancers, including cholangiocarcinoma (CHOL), colon adenocarcinoma (COAD), esophageal carcinoma (ESCA), liver hepatocellular carcinoma (LIHC) and rectum adenocarcinoma (READ) (Figure 8). Unexpectedly, the high expression of HULC was negatively correlated with OS time in CHOL, while HULC expression was not significantly correlated with OS time in other cancers. Moreover, CHOL was a kind of GI cancers not included in our meta-analysis.

\section{DISCUSSION}

Because lncRNA can regulate gene expression through epigenetic modification, transcription and post-transcriptional translation, lncRNAs have key functions in various diseases [45]. It has been found that IncRNAs are critical for angiogenesis and neuroprotection. Therefore, IncRNAs were considered as therapeutic, diagnostic and prognostic tools in cerebrovascular diseases, including stroke [17]. Recently, lncRNA has been proved to be a key factor in tumorigenesis, and it can involve in cancer by regulating tumor cell proliferation, migration and DNA stability [46]. In gynecological cancer, IncRNA is considered as a biomarker or therapeutic target [20]. LncRNAs such as MALAT1, XIST and NORAD have been proven to be biomarkers for human tumor prognosis [47-49]. Also, some studies have shown that HULC expression is dysregulated in digestive system tumors $[37,39,50]$. Therefore, we believe that HULC can be used as a new potential diagnostic and prognostic tumor biomarker for digestive system tumors.
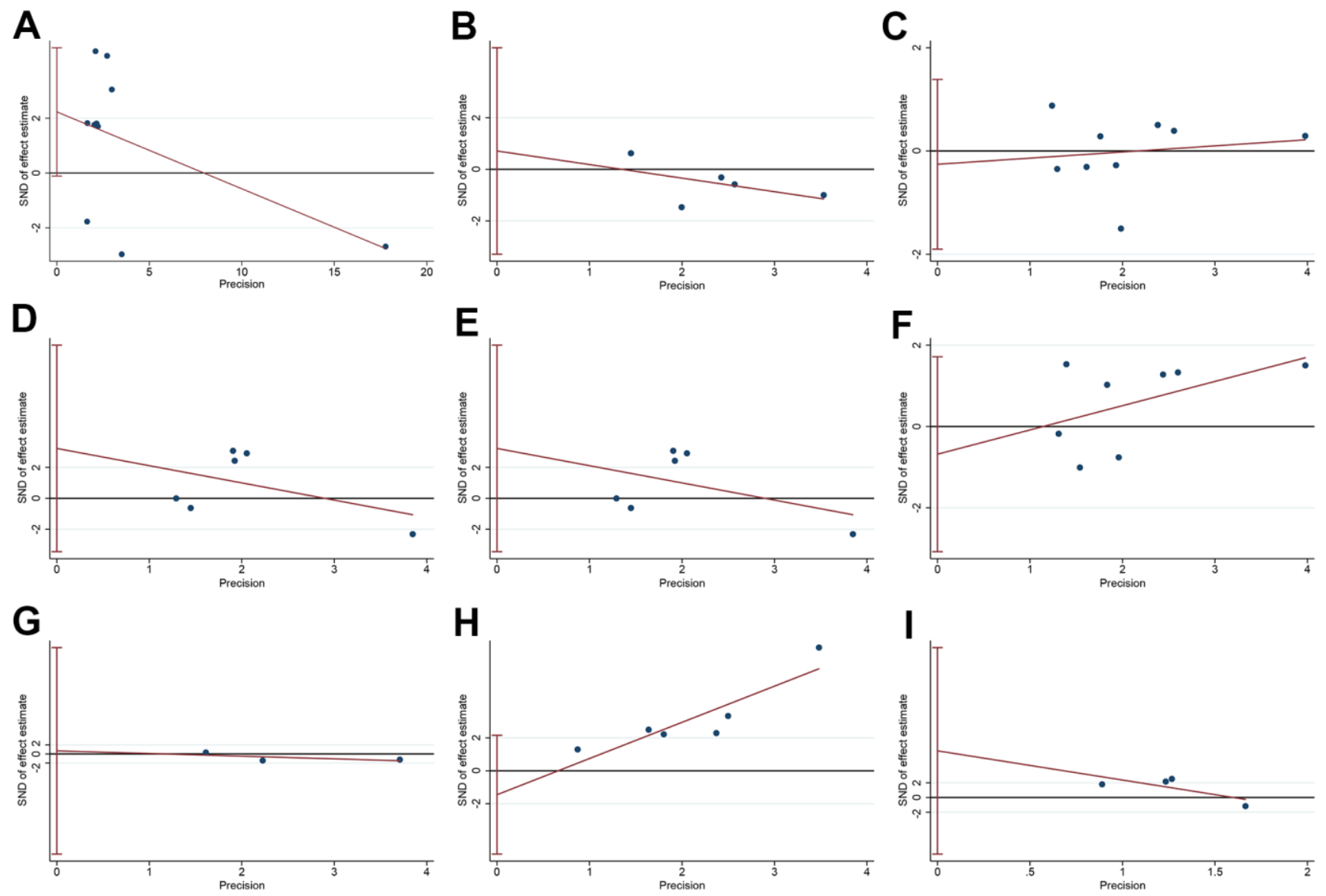

Figure 7. The publication bias of HULC-related research. (A) The Egger's test and linear regression plot for the publication bias of OS; (B) The Egger's test and linear regression plot for the publication bias of age; (C) The Egger's test and linear regression plot for the publication bias of gender; (D) The Egger's test and linear regression plot for the publication bias of tumor size; (E) The Egger's test and linear regression plot for the publication bias of TNM stage; (F) The Egger's test and linear regression plot for the publication bias of differentiation; (G) The Egger's test and linear regression plot for the publication bias of number of tumors; $(\mathbf{H})$ The Egger's test and linear regression plot for the publication bias of lymphatic node metastasis; (I) The Egger's test and linear regression plot for the publication bias of distant metastasis. 
We conducted this meta-analysis to verify the correlation between HULC expression level and survival prognosis of patients with digestive system tumors. A total of 14 studies involving 1312 patients were included. The pooled results suggested that high expression level of HULC had a significant correlation with poor survival prognosis in patients with digestive system tumors. Sensitivity analysis showed that our analysis was robust. We found that high expression level of HULC could increase the risk of high TNM stage, poor differentiation, and LNM. HULC expression level was not associated with age, gender, tumor size, number of tumors, or DM. The results of subgroup analysis suggested that cancer type and region were the sources of heterogeneity in this meta-analysis. There was no significant publication bias among all included studies. These results suggested that HULC may be a candidate oncogene for digestive system tumors. The up-regulated of HULC could be used as a novel predictor of poor prognosis in patients with digestive system tumors.
Since most studies prefer to report positive results rather than negative results. We performed a further verification for prognostic value of HULC in patients with digestive system tumors. By analyzing TCGA and GTEX data set, we found unexpected results. The high expression of HULC was negatively correlated with OS time in CHOL, while HULC expression was not significantly correlated with OS time in other cancers. This finding deserves further investigation.

According to previous reports, HULC can exert oncogenic effect through different mechanisms. Many cancer researchers have made great efforts to explore the functional mechanism of IncRNA HULC on the occurrence and development of various cancers. YB-1 is a multifunctional protein that participates in cellular functions, such as transcription regulation, mRNA splicing and translation regulation [51, 52]. It has been reported that HULC can promote the phosphorylation of YB-1 protein to activate the translation of silent
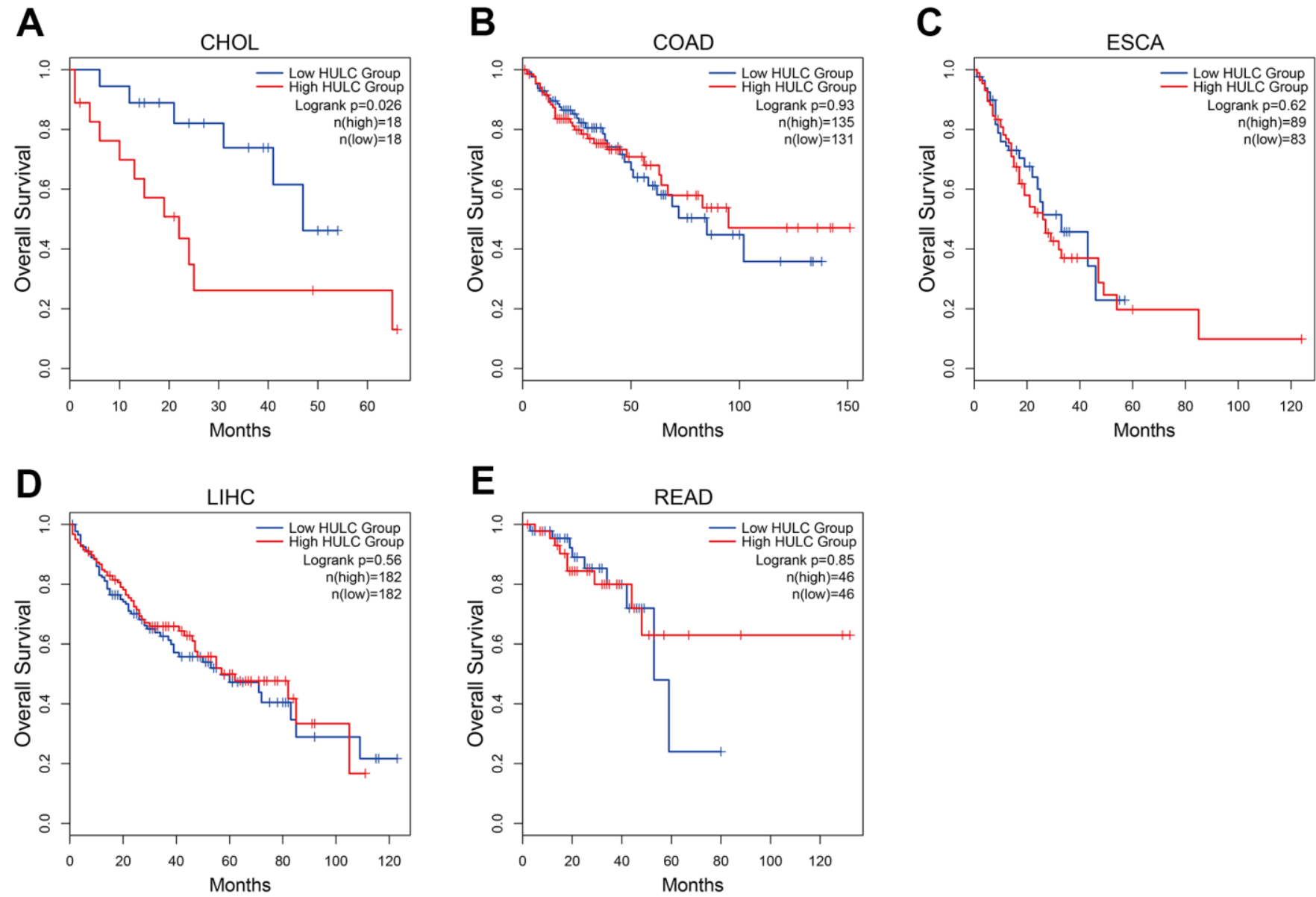

Figure 8. Kaplan-Meier curves showing the prognostic value of HULC in TCGA and GTEx data set. (A) The Kaplan-Meier curve of CHOL; (B) The Kaplan-Meier curve of COAD; (C) The Kaplan-Meier curve of ESCA; (D) The Kaplan-Meier curve of LIHC; (E) The Kaplan-Meier curve of READ. CHOL: cholangiocarcinoma; COAD: colon adenocarcinoma; ESCA: esophageal carcinoma; LIHC: liver hepatocellular carcinoma; READ: rectum adenocarcinoma. 
oncogenes, so as to promote the occurrence of hepatocellular carcinoma [53]. The "Warburg effect" refers to the reprogramming of glucose metabolism from oxidative phosphorylation to aerobic glycolysis, which is one of the hallmarks of tumor cells [54]. Wang et al. have found that HULC can enhance the binding of LDHA and PKM2 to FGFR1, resulting in increased phosphorylation of these two enzymes and consequently promoting glycolysis [55]. Non-coding RNAs (ncRNAs) can transfer information from their donor cells to recipient cells through exosomes to play a role in cell-tocell communication [56]. Circulating extracellular vesicle-encapsulated HULC showed good predictive performance in distinguishing pancreatic ductal adenocarcinoma (PDAC) [57]. Takahashi et al. 2020 et al. reported that miR-622 encapsulated by exosomes can inhibit epithelial-mesenchymal transition (EMT) by targeting HULC to inhibit the invasion and migration of pancreatic ductal adenocarcinoma cells [58]. Autophagy is recognized an intracellular regulatory process [10]. There is evidence that autophagy plays an important role in both progression and suppression of digestive system tumors [1, 10]. Thus, HULC can not only increase the expression of P62 by reducing mature miR-15a, but also increase autophagy by increasing Sirt1-dependent LC3II to promote the development of hepatocellular carcinoma [59]. STAT3, a transcription factor involved in immune response, inflammation and tumorigenesis, has been found to be critical for compensatory liver regeneration and chemically-induced HCC development [60]. Liu et al. indicated that HULC can elevate $\mathrm{HBx}$, which coactivated the STAT3 to stimulate the miR-539 promoter, and then down regulated APOBEC3B to activate HBV in HBV-related hepatocellular carcinoma [61]. The expression of HULC and endothelial cell specific molecule 1 (ESM-1) in glioma tissue is positively correlated with microvessel density and hierarchical dependence. Thus, the pro-angiogenic activity mechanism of HULC may be achieved by regulating ESM-1 through the $\mathrm{PI} 3 \mathrm{~K} / \mathrm{Akt} / \mathrm{mTOR}$ signal transduction pathway [62].

We found several meta-analyses evaluating the correlation between HULC expression level and prognosis. However, there is some difference between our study and the previous meta-analyses. First, the inclusion criteria are different. The previously metaanalyses evaluated the correlation between HULC expression and survival prognosis of cancer patients. These meta-analyses included various cancers. However, our study only included patients with digestive system tumors. A meta-analysis by $\mathrm{Li}$ et al. has no restrictions on the language of the publications [63]. Secondly, the number of eligible studies is increased significantly. The publications related to digestive system tumors included in the previous meta- analyses was 4-6, while we included 14 studies reporting digestive system tumors [29, 63-66]. Third, previous studies do not evaluate the correlation between HULC expression levels and tumor differentiation. Our meta-analysis confirms the association between HULC expression levels and survival prognosis in patients with digestive system tumors, and adds the analysis of tumor size, number of tumors, differentiation, age and gender of patients. Finally, although most of the studies were from China, this meta-analysis also included studies from South Korea, Japan and Germany.

However, this study still has some obvious limitations. First, Due to the complexity of digestive cancer types, the mechanism of HULC may be different among digestive system tumors. Then, there was no uniform cut-off value to define high HULC expression and low HULC expression. All included studies divided patients into high HULC expression group and low HULC expression group by mean or median. Third, the limited number of eligible studies and data in the analyses, leading to low statistical power and incomplete results. The HR and 95\% CI extracted from the Kaplan-Meier curve were far less reliable than the values directly provided by original studies. Since the extracted HR and $95 \% \mathrm{CI}$ could be affected by the subjective factors, it may lead to deviations of calculation. Next, the heterogeneity could not be completely improved, though the results of sensitivity analysis showed that our results were relatively robust. Finally, most of the included studies were from China, and the rest came from South Korea, Japan, and Germany. This limited the results of the study by region and ethnicity. Therefore, the results of this meta-analysis should be treated with caution for other ethnic groups.

In conclusion, this meta-analysis confirms that patients with up-regulated HULC may cause poorer clinical outcomes. Our results also show that the high expression level of HULC in serum and plasma was related to poor survival prognosis. HULC, especially from serum and plasma, can be used as a new potential predictor of the prognosis of patients with digestive system tumors. High expression of HULC increases the risk of high tumor stage, poor differentiation, and LNM in digestive system tumors. In view of the limitations mentioned above, it is necessary to conduct a more carefully designed study with diverse ethnic groups and large sample sizes to confirm the results of this metaanalysis and determine the predictive value of HULC in the prognosis of digestive system tumors.

\section{Ethics approval and consent to participate}

Ethical approval was not needed because this is a metaanalysis. 


\section{Availability of data and material}

The datasets used and/or analysed during the current study are available from the corresponding author on reasonable request.

\section{Abbreviations}

PC: pancreatic cancer; HCC: hepatocellular carcinoma; GC: gastric cancer; CRC: colorectal cancer; CC: colon cancer; CA: colon adenocarcinoma; OS: overall survival; DFS: disease-free survival; RFS: recurrence-free survival; HR: hazard ratio; CI: confidence interval; OR: odds ratio; TNM: tumor node metastasis; LNM: lymph node metastasis; DM: distant metastasis; WHO: World Health Organization; lncRNA: Long non-coding RNA; circRNA: circular RNA; miRNA: microRNA; HULC: Highly up-regulated in liver cancer; qRT-PCR: quantitative real-time polymerase chain reaction; $\mathrm{CHOL}$ : cholangiocarcinoma; COAD: colon adenocarcinoma; ESCA: esophageal carcinoma; LIHC: liver hepatocellular carcinoma; READ: rectum adenocarcinoma; MALAT1: metastasis-associated lung adenocarcinoma transcript 1; XIST: $X$-inactive specific transcript; NORAD: noncoding RNA activated by DNA damage; YB-1: Y-box binding protein 1; LDHA: lactate dehydrogenase A; PKM2: pyruvate kinase M2; FGFR1: fibroblast growth factor receptor type 1; EMT: epithelial-mesenchymal transition; P62: sequestosome 1; LC3II: microtubuleassociated protein 1 light chain 3 alpha; VEGF: vascular endothelial growth factor; ESM-1: endothelial cell specific molecule 1; PI3K: phosphatidylinositol 3-kinase; Akt: protein kinase B; mTOR: mammalian target of rapamycin.

\section{AUTHOR CONTRIBUTIONS}

LD, WR, WN, YYQ: Critical revision of the manuscript; LD, WR, WN, YYQ: Substantial contribution to the conception and design of the work, manuscript drafting; LD, WR, WN, YYQ: Acquisition, analysis, and interpretation of the data; LD, WR, WN, YYQ: Revising the manuscript critically, final approval of the version to be published. All authors have read and approved the final manuscript.

\section{CONFLICTS OF INTEREST}

All the authors declare that they have no conflicts of interest.

\section{REFERENCES}

1. Shafabakhsh R, Arianfar F, Vosough M, Mirzaei HR, Mahjoubin-Tehran $M$, Khanbabaei $H$, Kowsari $H$, Shojaie L, Azar ME, Hamblin MR, Mirzaei H. Autophagy and gastrointestinal cancers: the behind the scenes role of long non-coding RNAs in initiation, progression, and treatment resistance. Cancer Gene Ther. 2021; 28:1229-55.

https://doi.org/10.1038/s41417-020-00272-7 PMID:33432087

2. Sarvizadeh M, Hasanpour O, Naderi Ghale-Noie Z, Mollazadeh S, Rezaei M, Pourghadamyari H, Masoud Khooy M, Aschner M, Khan H, Rezaei N, Shojaie L, Mirzaei H. Allicin and Digestive System Cancers: From Chemical Structure to Its Therapeutic Opportunities. Front Oncol. 2021; 11:650256.

https://doi.org/10.3389/fonc.2021.650256 PMID:33987085

3. Siegel RL, Miller KD, Jemal A. Cancer statistics, 2019. CA Cancer J Clin. 2019; 69:7-34. https://doi.org/10.3322/caac.21551 PMID:30620402

4. Feng RM, Zong YN, Cao SM, Xu RH. Current cancer situation in China: good or bad news from the 2018 Global Cancer Statistics? Cancer Commun (Lond). 2019; 39:22.

https://doi.org/10.1186/s40880-019-0368-6 PMID:31030667

5. Ashrafizadeh $M$, Zarrabi $A$, Hashemipour $M$, Vosough M, Najafi M, Shahinozzaman M, Hushmandi K, Khan H, Mirzaei $H$. Sensing the scent of death: modulation of microRNAs by Curcumin in gastrointestinal cancers. Pharmacol Res. 2020; 160:105199.

https://doi.org/10.1016/i.phrs.2020.105199 PMID:32942019

6. Miller KD, Siegel RL, Lin CC, Mariotto AB, Kramer JL, Rowland JH, Stein KD, Alteri R, Jemal A. Cancer treatment and survivorship statistics, 2016. CA Cancer J Clin. 2016; 66:271-89.

https://doi.org/10.3322/caac.21349

PMID:27253694

7. Torre LA, Bray F, Siegel RL, Ferlay J, Lortet-Tieulent J, Jemal A. Global cancer statistics, 2012. CA Cancer J Clin. 2015; 65:87-108.

https://doi.org/10.3322/caac.21262

PMID:25651787

8. Hashemian SM, Pourhanifeh $\mathrm{MH}$, Fadaei S, Velayati AA, Mirzaei $H$, Hamblin MR. Non-coding RNAs and Exosomes: Their Role in the Pathogenesis of Sepsis. Mol Ther Nucleic Acids. 2020; 21:51-74. https://doi.org/10.1016/i.omtn.2020.05.012 PMID:32506014

9. Ahluwalia P, Kolhe R, Gahlay GK. The clinical relevance of gene expression based prognostic signatures in colorectal cancer. Biochim Biophys Acta Rev Cancer. 2021; 1875:188513. https://doi.org/10.1016/j.bbcan.2021.188513 PMID:33493614 
10. Pourhanifeh $\mathrm{MH}$, Vosough $\mathrm{M}$, Mahjoubin-Tehran $\mathrm{M}$, Hashemipour M, Nejati M, Abbasi-Kolli M, Sahebkar A, Mirzaei H. Autophagy-related microRNAs: possible regulatory roles and therapeutic potential in and gastrointestinal cancers. Pharmacol Res. 2020; 161:105133.

https://doi.org/10.1016/i.phrs.2020.105133

PMID: 32822869

11. Naeli $\mathrm{P}$, Pourhanifeh $\mathrm{MH}$, Karimzadeh MR, Shabaninejad Z, Movahedpour A, Tarrahimofrad $H$, Mirzaei HR, Bafrani HH, Savardashtaki A, Mirzaei H, Hamblin MR. Circular RNAs and gastrointestinal cancers: epigenetic regulators with a prognostic and therapeutic role. Crit Rev Oncol Hematol. 2020; 145:102854.

https://doi.org/10.1016/i.critrevonc.2019.102854 PMID:31877535

12. Guo CJ, Zhang W, Gershwin ME. Long noncoding RNA IncKdm2b: A critical player in the maintenance of group 3 innate lymphoid cells. Cell Mol Immunol. 2018; 15:5-7.

https://doi.org/10.1038/cmi.2017.55 PMID:28690327

13. Ponting $\mathrm{CP}$, Oliver PL, Reik W. Evolution and functions of long noncoding RNAs. Cell. 2009; 136:629-41.

https://doi.org/10.1016/i.cell.2009.02.006

PMID:19239885

14. Bhan A, Soleimani M, Mandal SS, Long Noncoding RN. Long Noncoding RNA and Cancer: A New Paradigm. Cancer Res. 2017; 77:3965-81.

https://doi.org/10.1158/0008-5472.CAN-16-2634 PMID:28701486

15. Bhan A, Mandal SS. LncRNA HOTAIR: A master regulator of chromatin dynamics and cancer. Biochim Biophys Acta. 2015; 1856:151-64.

https://doi.org/10.1016/i.bbcan.2015.07.001 PMID:26208723

16. Wapinski O, Chang HY. Long noncoding RNAs and human disease. Trends Cell Biol. 2011; 21:354-61. https://doi.org/10.1016/i.tcb.2011.04.001 PMID:21550244

17. Mahjoubin-Tehran M, Rezaei S, Jesmani A, Birang $N$, Morshedi K, Khanbabaei $H$, Khan $H$, Piranviseh A, Nejati M, Aschner M, Mirzaei $H$. New epigenetic players in stroke pathogenesis: from non-coding RNAs to exosomal non-coding RNAs. Biomed Pharmacother. 2021; 140:111753.

https://doi.org/10.1016/j.biopha.2021.111753 PMID:34044272

18. Morán I, Akerman I, van de Bunt M, Xie R, Benazra M, Nammo T, Arnes L, Nakić N, García-Hurtado J, Rodríguez-Seguí S, Pasquali L, Sauty-Colace C, Beucher A, et al. Human $\beta$ cell transcriptome analysis uncovers
IncRNAs that are tissue-specific, dynamically regulated, and abnormally expressed in type 2 diabetes. Cell Metab. 2012; 16:435-48.

https://doi.org/10.1016/i.cmet.2012.08.010

PMID:23040067

19. Kogo R, Shimamura T, Mimori K, Kawahara K, Imoto S, Sudo T, Tanaka F, Shibata K, Suzuki A, Komune S, Miyano S, Mori M. Long noncoding RNA HOTAIR regulates polycomb-dependent chromatin modification and is associated with poor prognosis in colorectal cancers. Cancer Res. 2011; 71:6320-6. https://doi.org/10.1158/0008-5472.CAN-11-1021 PMID:21862635

20. Rahimian N, Razavi ZS, Aslanbeigi F, Mirkhabbaz AM, Piroozmand $\mathrm{H}$, Shahrzad MK, Hamblin MR, Mirzaei $\mathrm{H}$. Non-coding RNAs related to angiogenesis in gynecological cancer. Gynecol Oncol. 2021; 161:896-912.

https://doi.org/10.1016/i.ygyno.2021.03.020 PMID:33781555

21. Hashemipour M, Boroumand H, Mollazadeh S, Tajiknia V, Nourollahzadeh Z, Rohani Borj M, Pourghadamyari H, Rahimian N, Hamblin MR, Mirzaei H. Exosomal microRNAs and exosomal long non-coding RNAs in gynecologic cancers. Gynecol Oncol. 2021; 161:314-27. https://doi.org/10.1016/i.ygyno.2021.02.004 PMID:33581845

22. Yu X, Zheng $H$, Chan MT, Wu WK. HULC: an oncogenic long non-coding RNA in human cancer. J Cell Mol Med. 2017; 21:410-7. https://doi.org/10.1111/jcmm.12956 PMID:27781386

23. Gavgani RR, Babaei E, Hosseinpourfeizi MA, Fakhrjou A, Montazeri V. Study of long non-coding RNA highly upregulated in liver cancer (HULC) in breast cancer: A clinical and in vitro investigation. Indian J Med Res. 2020; 152:244-53.

https://doi.org/10.4103/ijmr.IJMR $1823 \quad 18$ PMID:33107484

24. Ou ZL, Luo Z, Lu YB. Long non-coding RNA HULC as a diagnostic and prognostic marker of pancreatic cancer. World J Gastroenterol. 2019; 25:6728-42. https://doi.org/10.3748/wig.v25.i46.6728 PMID:31857775

25. Wang J, Ma W, Liu Y. Long non-coding RNA HULC promotes bladder cancer cells proliferation but inhibits apoptosis via regulation of ZIC2 and PI3K/AKT signaling pathway. Cancer Biomark. 2017; 20:425-34. https://doi.org/10.3233/CBM-170188 PMID:28946549

26. Panzitt K, Tschernatsch MM, Guelly C, Moustafa T, Stradner M, Strohmaier HM, Buck CR, Denk $H$, Schroeder R, Trauner M, Zatloukal K. Characterization of HULC, a novel gene with striking up-regulation in 
hepatocellular carcinoma, as noncoding RNA. Gastroenterology. 2007; 132:330-42.

https://doi.org/10.1053/j.gastro.2006.08.026

PMID: 17241883

27. Abdi E, Latifi-Navid S, Abdi F, Taherian-Esfahani Z. Emerging circulating MiRNAs and LncRNAs in upper gastrointestinal cancers. Expert Rev Mol Diagn. 2020; 20:1121-38.

https://doi.org/10.1080/14737159.2020.1842199

PMID:33103502

28. Dong $Y$, Wei MH, Lu JG, Bi CY. Long non-coding RNA HULC interacts with miR-613 to regulate colon cancer growth and metastasis through targeting RTKN. Biomed Pharmacother. 2019; 109:2035-42.

https://doi.org/10.1016/i.biopha.2018.08.017 PMID:30551459

29. Ding Y, Sun C, Li J, Hu L, Li M, Liu J, Pu L, Xiong S. The Significance of Long Non-coding RNA HULC in Predicting Prognosis and Metastasis of Cancers: a Meta-Analysis. Pathol Oncol Res. 2019; 25:311-8. https://doi.org/10.1007/s12253-017-0351-y PMID:29110261

30. Stang A. Critical evaluation of the Newcastle-Ottawa scale for the assessment of the quality of nonrandomized studies in meta-analyses. Eur J Epidemiol. 2010; 25:603-5. https://doi.org/10.1007/s10654-010-9491-z PMID:20652370

31. Tierney JF, Stewart LA, Ghersi D, Burdett S, Sydes MR. Practical methods for incorporating summary time-toevent data into meta-analysis. Trials. 2007; 8:16.

https://doi.org/10.1186/1745-6215-8-16 PMID:17555582

32. Tang Z, Kang B, Li C, Chen T, Zhang Z. GEPIA2: an enhanced web server for large-scale expression profiling and interactive analysis. Nucleic Acids Res. 2019; 47:W556-60.

https://doi.org/10.1093/nar/gkz430 PMID:31114875

33. Liu T, Liu Y, Wei C, Yang Z, Chang W, Zhang X. LncRNA HULC promotes the progression of gastric cancer by regulating miR-9-5p/MYH9 axis. Biomed Pharmacother. 2020; 121:109607.

https://doi.org/10.1016/i.biopha.2019.109607 PMID:31726371

34. Oehme F, Krahl S, Gyorffy B, Muessle B, Rao V, Greif H, Ziegler N, Lin K, Thepkaysone ML, Polster $\mathrm{H}$, Tonn $\mathrm{T}$, Schneider M, Weitz J, et al. Low level of exosomal long non-coding RNA HOTTIP is a prognostic biomarker in colorectal cancer. RNA Biol. 2019; 16:1339-45. https://doi.org/10.1080/15476286.2019.1637697 PMID:31251124
35. Cao SQ, Zheng H, Sun BC, Wang ZL, Liu T, Guo DH, Shen ZY. Long non-coding RNA highly up-regulated in liver cancer promotes exosome secretion. World J Gastroenterol. 2019; 25:5283-99.

https://doi.org/10.3748/wjg.v25.i35.5283

PMID:31558873

36. Zhang Z, Qian W, Wang S, Ji D, Wang Q, Li J, Peng W, Gu J, Hu T, Ji B, Zhang Y, Wang S, Sun Y. Analysis of IncRNA-Associated ceRNA Network Reveals Potential IncRNA Biomarkers in Human Colon Adenocarcinoma. Cell Physiol Biochem. 2018; 49:1778-91. https://doi.org/10.1159/000493623 PMID:30231249

37. Sonohara F, Inokawa $\mathrm{Y}$, Hayashi M, Yamada S, Sugimoto H, Fujii T, Kodera $Y$, Nomoto S. Prognostic Value of Long Non-Coding RNA HULC and MALAT1 Following the Curative Resection of Hepatocellular Carcinoma. Sci Rep. 2017; 7:16142.

https://doi.org/10.1038/s41598-017-16260-1 PMID:29170515

38. Zhang $Y$, Song $X$, Wang $X, H u ~ J$, Jiang L. Silencing of LncRNA HULC Enhances Chemotherapy Induced Apoptosis in Human Gastric Cancer. J Med Biochem. 2016; 35:137-43. https://doi.org/10.1515/jomb-2015-0016 PMID:28356873

39. Yang XJ, Huang CQ, Peng CW, Hou JX, Liu JY. Long noncoding RNA HULC promotes colorectal carcinoma progression through epigenetically repressing NKD2 expression. Gene. 2016; 592:172-8.

https://doi.org/10.1016/i.gene.2016.08.002 PMID:27496341

40. Li SP, Xu HX, Yu Y, He JD, Wang Z, Xu YJ, Wang CY, Zhang HM, Zhang RX, Zhang JJ, Yao Z, Shen ZY. LncRNA HULC enhances epithelial-mesenchymal transition to promote tumorigenesis and metastasis of hepatocellular carcinoma via the miR-200a-3p/ZEB1 signaling pathway. Oncotarget. 2016; 7:42431-46. https://doi.org/10.18632/oncotarget.9883 PMID:27285757

41. Jin C, Shi W, Wang F, Shen X, Qi J, Cong H, Yuan J, Shi L, Zhu $B$, Luo $X$, Zhang $Y$, Ju S. Long non-coding RNA HULC as a novel serum biomarker for diagnosis and prognosis prediction of gastric cancer. Oncotarget. 2016; 7:51763-72.

https://doi.org/10.18632/oncotarget.10107 PMID:27322075

42. Yang Z, Lu Y, Xu Q, Tang B, Park CK, Chen X. HULC and H19 Played Different Roles in Overall and Disease-Free Survival from Hepatocellular Carcinoma after Curative Hepatectomy: A Preliminary Analysis from Gene Expression Omnibus. Dis Markers. 2015; 2015:191029. 
https://doi.org/10.1155/2015/191029

PMID:26136615

43. Li J, Wang $X$, Tang J, Jiang $R$, Zhang W, Ji J, Sun B. HULC and Linc00152 Act as Novel Biomarkers in Predicting Diagnosis of Hepatocellular Carcinoma. Cell Physiol Biochem. 2015; 37:687-96. https://doi.org/10.1159/000430387 PMID:26356260

44. Peng W, Gao W, Feng J. Long noncoding RNA HULC is a novel biomarker of poor prognosis in patients with pancreatic cancer. Med Oncol. 2014; 31:346. https://doi.org/10.1007/s12032-014-0346-4 PMID:25412939

45. Lou W, Ding B, Fu P. Pseudogene-Derived IncRNAs and Their miRNA Sponging Mechanism in Human Cancer. Front Cell Dev Biol. 2020; 8:85.

https://doi.org/10.3389/fcell.2020.00085

PMID:32185172

46. Rathinasamy B, Velmurugan BK. Role of IncRNAs in the cancer development and progression and their regulation by various phytochemicals. Biomed Pharmacother. 2018; 102:242-8.

https://doi.org/10.1016/i.biopha.2018.03.077 PMID:29567536

47. Ye T, Ye Z. LncRNA NORAD as a Novel Predictor of Lymph Node Metastasis and Prognosis in Solid Tumors: A Systematic Review and Meta-Analysis. Technol Cancer Res Treat. 2020; 19:1533033820963586. https://doi.org/10.1177/1533033820963586 PMID:33016254

48. Deng C, Hu X, Wu K, Tan J, Yang C. Long non-coding RNA XIST predicting advanced clinical parameters in cancer: A Meta-Analysis and case series study in a single institution. Oncol Lett. 2019; 18:2192-202.

https://doi.org/10.3892/ol.2019.10592 PMID:31404342

49. Wei Y, Niu B. Role of MALAT1 as a Prognostic Factor for Survival in Various Cancers: A Systematic Review of the Literature with Meta-Analysis. Dis Markers. 2015; 2015:164635.

https://doi.org/10.1155/2015/164635 PMID:26420912

50. Wang WT, Ye H, Wei PP, Han BW, He B, Chen ZH, Chen YQ. LncRNAs $\mathrm{H} 19$ and HULC, activated by oxidative stress, promote cell migration and invasion in cholangiocarcinoma through a ceRNA manner. J Hematol Oncol. 2016; 9:117. https://doi.org/10.1186/s13045-016-0348-0 PMID:27809873

51. Lyabin DN, Eliseeva IA, Ovchinnikov LP. YB-1 protein: functions and regulation. Wiley Interdiscip Rev RNA. 2014; 5:95-110. https://doi.org/10.1002/wrna.1200 PMID:24217978
52. Wolffe AP. Structural and functional properties of the evolutionarily ancient Y-box family of nucleic acid binding proteins. BioEssays. 1994; 16:245-51.

https://doi.org/10.1002/bies.950160407 PMID:8031301

53. Li D, Liu X, Zhou J, Hu J, Zhang D, Liu J, Qiao Y, Zhan Q. Long noncoding RNA HULC modulates the phosphorylation of YB-1 through serving as a scaffold of extracellular signal-regulated kinase and YB-1 to enhance hepatocarcinogenesis. Hepatology. 2017; 65:1612-27.

https://doi.org/10.1002/hep.29010 PMID:28027578

54. Mirzaei H, Hamblin MR. Regulation of Glycolysis by Non-coding RNAs in Cancer: Switching on the Warburg Effect. Mol Ther Oncolytics. 2020; 19:218-39. https://doi.org/10.1016/j.omto.2020.10.003 PMID:33251334

55. Wang C, Li Y, Yan S, Wang H, Shao X, Xiao M, Yang B, Qin $\mathrm{G}$, Kong $\mathrm{R}$, Chen $\mathrm{R}$, Zhang N. Interactome analysis reveals that IncRNA HULC promotes aerobic glycolysis through LDHA and PKM2. Nat Commun. 2020; 11:3162. https://doi.org/10.1038/s41467-020-16966-3 PMID: $\underline{2572027}$

56. Tkach $M$, Théry $C$. Communication by Extracellular Vesicles: Where We Are and Where We Need to Go. Cell. 2016; 164:1226-32.

https://doi.org/10.1016/i.cell.2016.01.043 PMID:26967288

57. Takahashi K, Ota $Y$, Kogure $T$, Suzuki $Y$, Iwamoto $H$, Yamakita K, Kitano Y, Fujii S, Haneda M, Patel T, Ota T. Circulating extracellular vesicle-encapsulated HULC is a potential biomarker for human pancreatic cancer. Cancer Sci. 2020; 111:98-111. https://doi.org/10.1111/cas.14232 PMID:31715081

58. Takahashi K, Koyama K, Ota Y, Iwamoto H, Yamakita K, Fujii S, Kitano Y. The Interaction Between Long Noncoding RNA HULC and MicroRNA-622 via Transfer by Extracellular Vesicles Regulates Cell Invasion and Migration in Human Pancreatic Cancer. Front Oncol. 2020; 10:1013.

https://doi.org/10.3389/fonc. 2020.01013

PMID: $\underline{2656089}$

59. Xin $X$, Wu $M$, Meng $Q$, Wang $C$, Lu $Y$, Yang $Y$, Li X, Zheng Q, Pu H, Gui X, Li T, Li J, Jia S, Lu D. Long noncoding RNA HULC accelerates liver cancer by inhibiting PTEN via autophagy cooperation to miR15a. Mol Cancer. 2018; 17:94.

https://doi.org/10.1186/s12943-018-0843-8 PMID:29895332

60. He G, Karin M. NF-KB and STAT3 - key players in liver inflammation and cancer. Cell Res. 2011; 21:159-68. 
https://doi.org/10.1038/cr.2010.183

PMID:21187858

61. Liu $Y$, Feng J, Sun $M$, Yang $G$, Yuan $H$, Wang $Y, B u Y$, Zhao $\mathrm{M}$, Zhang $\mathrm{S}$, Zhang $\mathrm{X}$. Long non-coding RNA HULC activates $\mathrm{HBV}$ by modulating $\mathrm{HBx} / \mathrm{STAT3} / \mathrm{miR}$ 539/APOBEC3B signaling in HBV-related hepatocellular carcinoma. Cancer Lett. 2019; 454:158-70.

https://doi.org/10.1016/i.canlet.2019.04.008

PMID:30981758

62. Zhu Y, Zhang X, Qi L, Cai Y, Yang P, Xuan G, Jiang Y. HULC long noncoding RNA silencing suppresses angiogenesis by regulating ESM-1 via the $\mathrm{PI3K} / \mathrm{Akt} / \mathrm{mTOR}$ signaling pathway in human gliomas. Oncotarget. 2016; 7:14429-40.

https://doi.org/10.18632/oncotarget.7418

PMID:26894862

63. Li Y, Liu YH, Chen X, Zhu YJ, Zhang HB, Li Y, Bai JP, Liu LR, Qu YC, Qu X. Effect of long non-coding RNA highly upregulated in liver cancer (HULC) on the prognosis of cancer: a meta-analysis. Oncotarget. 2017; 8:83246-50. https://doi.org/10.18632/oncotarget.18452

PMID:29137338

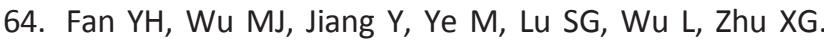
Long non-coding RNA HULC as a potential prognostic biomarker in human cancers: a meta-analysis. Oncotarget. 2017; 8:21410-7. https://doi.org/10.18632/oncotarget.15247 PMID:28199963

65. Chen $X$, Lun L, Hou H, Tian R, Zhang H, Zhang Y. The Value of IncRNA HULC as a Prognostic Factor for Survival of Cancer Outcome: A Meta-Analysis. Cell Physiol Biochem. 2017; 41:1424-34. https://doi.org/10.1159/000468005 PMID:28315877

66. Wang $Y$, Huang $Y$, Xiang $P$, Tian $W$. LncRNA expression and implication in osteosarcoma: a systematic review and meta-analysis. Onco Targets Ther. 2017; 10:5355-61. https://doi.org/10.2147/OTT.S149889 PMID:29184421 